\title{
Bacillus subtilis SbcC protein plays an important role in DNA inter-strand cross-link repair
}

\author{
Judita Mascarenhas $^{\dagger 1,3}$, Humberto Sanchez ${ }^{\dagger 2}$, Serkalem Tadesse ${ }^{1}$, \\ Dawit Kidane ${ }^{1}$, Mahalakshmi Krisnamurthy ${ }^{1}$, Juan C Alonso ${ }^{2}$ and \\ Peter L Graumann*1
}

Address: ${ }^{1}$ Institut für Mikrobiologie, Albert-Ludwigs Universität Freiburg, Stefan Meier Str. 19, 79104 Freiburg, Germany, ${ }^{2}$ Departamento de Biotecnología Microbiana, Centro Nacional de Biotecnología, CSIC, C/Darwin 3, Campus Universidad Autónoma de Madrid, Cantoblanco, 28049 Madrid, Spain and ${ }^{3}$ Institut für Klinische Zytobiologie und Zytopathologie, Robert-Koch-Straße 6, 35037 Marburg, Germany

Email: Judita Mascarenhas - m_judith@yahoo.com; Humberto Sanchez - hsanchez@cnb.uam.es; Serkalem Tadesse - serkalem.tadesse@biologie.uni-freiburg.de; Dawit Kidane - dawit.kidane@biologie.uni-freiburg.de; Mahalakshmi Krisnamurthy - maha@biologie.uni-freiburg.de; Juan C Alonso - jcalonso@cnb.uam.es; Peter L Graumann* - peter.graumann@biologie.uni-freiburg.de

* Corresponding author †Equal contributors

Published: 16 June 2006

BMC Molecular Biology 2006, 7:20 doi:10.1 186/147/-2199-7-20
Received: 06 January 2006

Accepted: 16 June 2006

This article is available from: http://www.biomedcentral.com/I47I-2199/7/20

(C) 2006 Mascarenhas et al; licensee BioMed Central Ltd.

This is an Open Access article distributed under the terms of the Creative Commons Attribution License (http://creativecommons.org/licenses/by/2.0), which permits unrestricted use, distribution, and reproduction in any medium, provided the original work is properly cited.

\begin{abstract}
Background: Several distinct pathways for the repair of damaged DNA exist in all cells. DNA modifications are repaired by base excision or nucleotide excision repair, while DNA double strand breaks (DSBs) can be repaired through direct joining of broken ends (non homologous end joining, NHEJ) or through recombination with the non broken sister chromosome (homologous recombination, HR). Rad50 protein plays an important role in repair of DNA damage in eukaryotic cells, and forms a complex with the Mrell nuclease. The prokaryotic ortholog of Rad50, SbcC, also forms a complex with a nuclease, SbcD, in Escherichia coli, and has been implicated in the removal of hairpin structures that can arise during DNA replication. Ku protein is a component of the NHEJ pathway in pro- and eukaryotic cells.

Results: A deletion of the $s b c C$ gene rendered Bacillus subtilis cells sensitive to DNA damage caused by Mitomycin C (MMC) or by gamma irradiation. The deletion of the $s b c C$ gene in a recN mutant background increased the sensitivity of the single recN mutant strain. SbcC was also non-epistatic with AddAB (analog of Escherichia coli RecBCD), but epistatic with RecA. A deletion of the $y k o V$ gene encoding the $B$. subtilis $K u$ protein in a $s b c C$ mutant strain did not resulted in an increase in sensitivity towards MMC and gamma irradiation, but exacerbated the phenotype of a recN or a recA mutant strain. In exponentially growing cells, SbcC-GFP was present throughout the cells, or as a central focus in rare cases. Upon induction of DNA damage, SbcC formed I, rarely 2, foci on the nucleoids. Different to RecN protein, which forms repair centers at any location on the nucleoids, $\mathrm{SbcC}$ foci mostly co-localized with the DNA polymerase complex. In contrast to this, AddA-GFP or AddB-GFP did not form detectable foci upon addition of MMC.

Conclusion: Our experiments show that SbcC plays an important role in the repair of DNA inter-strand cross-links (induced by MMC), most likely through HR, and suggest that NHEJ via Ku serves as a backup DNA repair system. The cell biological experiments show that $\mathrm{SbcC}$ functions in close proximity to the replication machinery, suggesting that $\mathrm{SbcC}$ may act on stalled or collapsed replication forks. Our results show that different patterns of localization exist for DNA repair proteins, and that the B. subtilis SMC proteins $\operatorname{RecN}$ and SbcC play distinct roles in the repair of DNA damage.
\end{abstract}




\section{Background}

All organisms need to ensure the integrity of their genome. A major threat are inter-strand cross-links and double strand breaks (DSBs) in the DNA that can cause cell death or cellular transformation. The repair of interstrand cross-links appears to be achieved via two pathways, including proteins involved in nucleotide excision repair, and DNA polymerase II or proteins mediating homologous recombination (HR) [1]. At least two pathways also exist for the repair of DSBs. These can be repaired through direct end joining (non homologous end joining, NHEJ), but this process creates the danger of connecting the wrong ends, and of losing genetic information. In eukaryotic and in some prokaryotic cells, Ku protein binds to broken DNA ends, protects them from exonucleolytic degradation and specifically recruits a dedicated DNA ligase that seals the ends [2,3]. In Bacillus subtilis, deletion of the genes encoding for $\mathrm{Ku}$ and DNA ligase ( $y k o V$ and $y k o U$ ) leads to sensitivity to DSBs during stationary phase [4], showing that this pathway has an important function in non-growing cells. A much less error prone pathway is DNA repair through HR, in which a variety of proteins uses the intact sister chromosome to fix a DSB [5-7]. Central to this pathway is strand exchange protein RecA (Rad51 in eukaryotes) that promotes the annealing of the 3'-single-stranded (ss) DNA from the broken chromosome with the homologous sister copy and thereby catalyzes HR. In B. subtilis, the AddAB (nuclease/helicase) complex (RecBCD in Escherichia coli) or alternatively, RecQ/RecS/RecJ act upstream of RecA. These enzymes generate a ssDNA region at the DSB, which is used for strand exchange [8]. AddAB or RecO/RecR load or help to load RecA onto the 3' ssDNA end [9]. In eukaryotes, the Rad50/Mre11/Xrs2 (Nbs1 in human cells) complex is thought to perform the degradation of one DNA strand to generate a 3' ssDNA overhang. Downstream of RecA, different DNA helicases, such as RecG, and the Ruv$\mathrm{ABC}$ complex are involved in the formation of Holliday junctions and in the resolution of crossovers [6], while DNA polymerase $\mathrm{I}$ is required to fill ssDNA gaps.

The eukaryotic Rad50 complex plays an important role in DNA repair in eukaryotes through $\operatorname{HR}[10,11]$, and is apparently also involved in NHEJ through bridging of the broken DNA ends [12,13]. Mre11 has endo- and exonuclease activity in the presence of Rad50 [14]. Rad50 has been shown to bind to DNA in an ATP-dependent manner [15], although the Rad50 complex was found to be able to bind to DNA in the absence of ATP [16]; DNA end-bridging is ATP independent [17]. Rad50 belongs to the family of SMC proteins that share a similar modular structure. These proteins are composed of conserved $\mathrm{N}$ - and $\mathrm{C}$ - terminal domains that are separated by two long coiled coil domains and a central hinge domain. Two monomers invariably form a dimer through specific interaction of the hinge domains, creating a symmetrical dimer with a central hinge, two long coiled coil arms and two ATPase head domains $[18,19]$. In Rad50, the coiled coil arms lack a hinge domain. Instead, the coiled coils can connect in a dynamic manner via a $\mathrm{Zn}$ bridge formed by an invariable CxxC motif, which may mediate end bridging [20]. SMC proteins are central components of several essential protein complexes in pro- and eukaryotes, and mediate a wide range of chromosome dynamics [21]. In bacteria, the SMC complex localizes as two foci, one within each cell half, and actively compacts and organises chromosomes from these sites [22]. The chromosome is replicated in and moves through the centrally located DNA polymerase complex [23]. Thus, bacterial chromosomes are segregated during ongoing replication, while both processes occur at different times during the cell cycle in eukaryotic cells.

In E. coli, the Rad50 ortholog, SbcC, forms a complex with the Mre11-homologous SbcD nuclease [24], which has been shown to be involved in cleavage of DNA hairpins that can occur during replication [25]. Many other bacteria possess $s b c C$ homologous genes, but no reports on SbcC in other bacteria are available, and it is unclear if SbcC plays a similar role in DNA repair as Rad50 in eukaryotes.

In recent years, repair of DNA DSBs has been visualized in live eukaryotic cells, giving vital insight into the function of proteins. The Rad50 complex, Rad51, Rad52 and other repair proteins have been shown to form discrete foci on damaged chromosomes, and to dynamically interact within the repair structures, or to form distinct repair foci [26-30]. In bacteria, RecA, RecN, RecO and RecF have been shown to co-localize to discrete centres on the nucleoids after induction of DNA damage, showing that bacteria also form DNA repair centres after DNA damage [31,32]. RecN is also a member of the SMC protein family, plays an important function in DNA repair via $H R$, and has ssDNA-binding activity in vitro $[8,33]$.

In this work, we have investigated the role of prokaryotic SbcC in DNA repair, and show it has an important function in this process, which is different from that of RecN. We have visualized the dynamic formation of defined SbcC foci on the DNA in response to DNA damage. The foci were generally coincident with the position of the replication machinery, and therefore most likely represent stalled replication forks, whose restart may be facilitated by the action of SbcC.

\section{Results}

\section{B. subtilis SbcC is involved in DNA repair}

BLAST searches showed that the yirY gene in the B. subtilis genome encodes a typical SbcC protein, with a central 

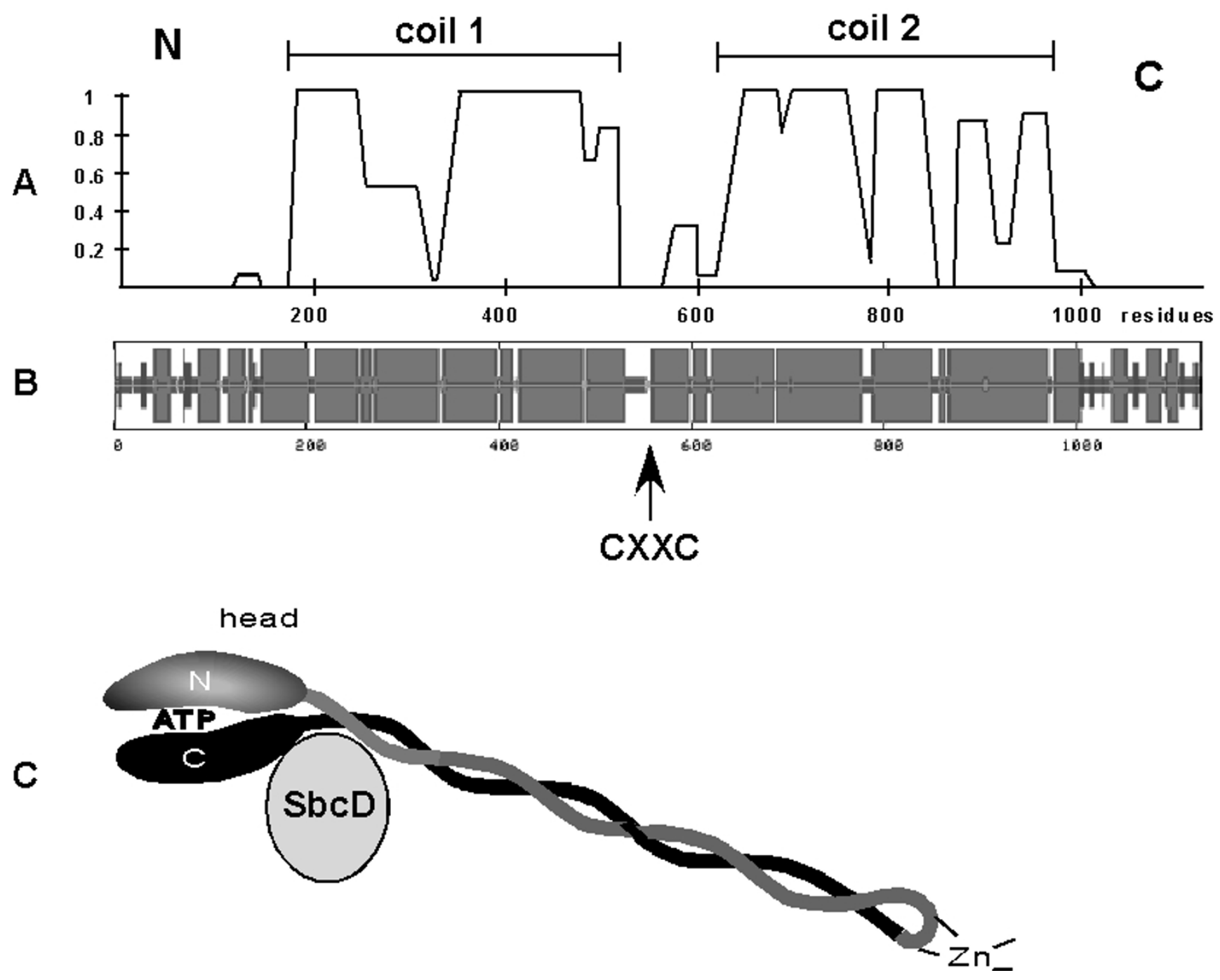

Figure I

A) Analysis of the probability of coiled coil regions within B. subtilis SbcC, using programs from http://npsa-pbil.ibcp.fr. The position of the corresponding CXXC motif forming a Zn bridge in Rad50 [20] is indicated. B) Analysis of the formation of $\alpha$-helices in SbcC. C) Putative structure of SbcC, and putative binding of SbcD, according to data obtained for Rad50 protein [18, 56]. $\mathrm{SbcC}$ has the potential to form a dimer with another SbcC monomer via the Zn-bridge. It is interesting to note that in spite of their similarity, the SbcCD and Rad50/Mre I I complexes have a different arrangement in vitro [57].

CXXC motif (residues 537-540), N- and C-terminal ATPase cassette domains and two long coiled coil domains (Fig. 1). The yirY gene product is a $128.7 \mathrm{kDa}$ protein with a pI of 5.3, and is most similar to E. coli SbcC, and significantly homologous to eukaryotic Rad50 proteins (C-terminal domain: 30\% identity/49\% similarity to SbcC, $18 \%$ identity/26\% similarity to S. cerevisiae Rad50). $\mathrm{SbcC}$ is in a putative operon with and downstream of $a d d B, a d d A$ and $s b c D$ genes [E. coli SbcC forms a complex with SbcD [24]], and upstream of $y i s B$. Therefore, we propose to name the yirY gene product SbcC of B. subtilis, and the gene $s b c C$. To test the function of $\mathrm{SbcC}$, we constructed a gene disruption of $s b c C$. Because the gene downstream of $s b c C$, yisB, performs an important function during growth in B. subtilis (our unpublished data), we cloned an internal fragment of $s b c C$ into an integration vector that contains a xylose inducible promoter $\left(\mathrm{P}_{x y l}\right)$ for transcription of downstream genes. Integration of the vector into the $s b c C$ gene resulted in the disruption of the gene, while transcription of $y i s B$ continued through the $\mathrm{P}_{x y l}$ promoter. Disruption of $s b c C$ did not show any effect on normal growth of $B$. subtilis cells, but markedly affected DNA repair. When strain JM42 $(s b c C:: \mathrm{cm})$ was challenged with 50 or $100 \mathrm{ng} / \mathrm{ml}$ of Mitomycin C \{MMC forms base adducts and DNA inter-strand cross-links (in a $\sim 4: 1$ ratio), which can lead to single strand gaps and to DSBs [34- 


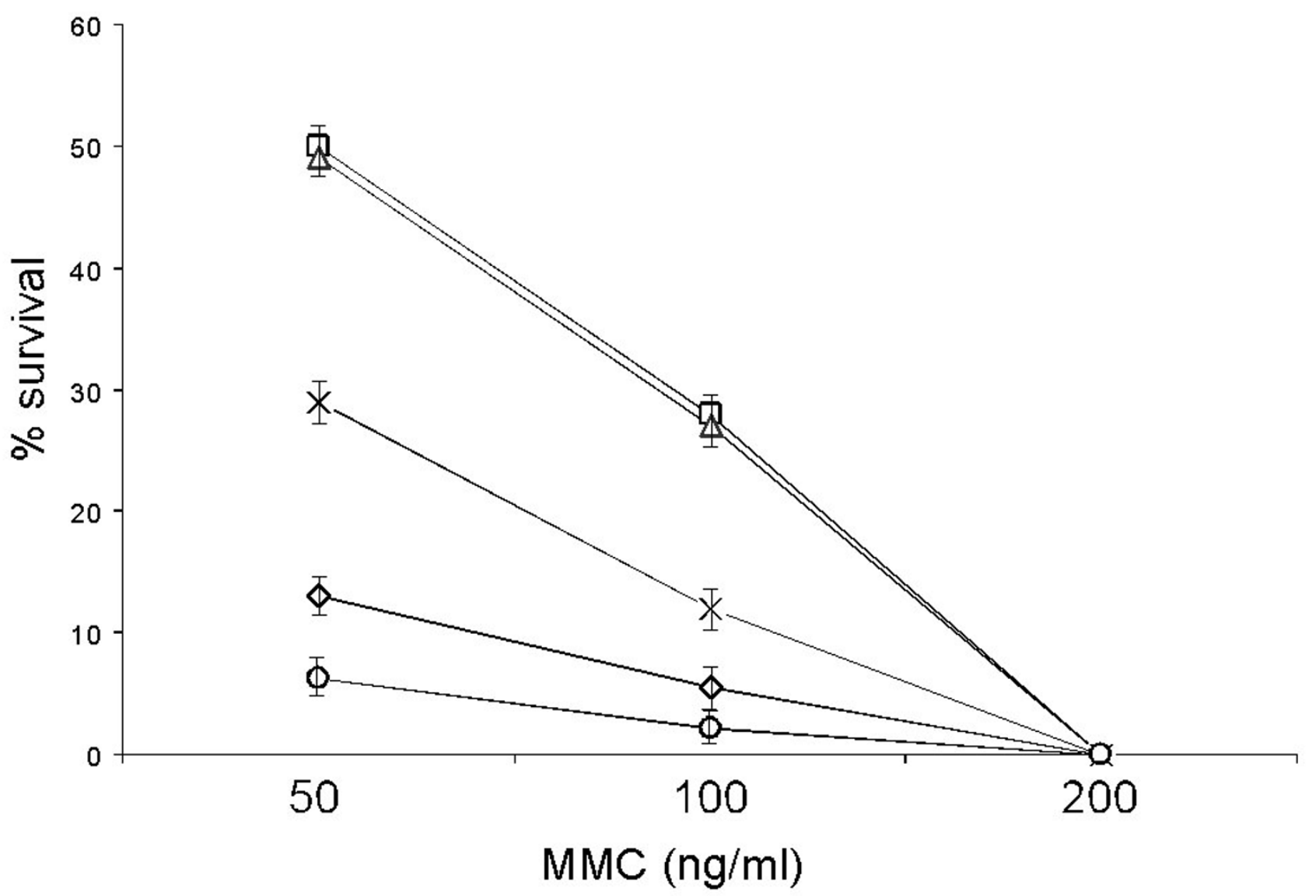

$\square$ PY79 (wt) $\triangle$ SbcC-YFP $\diamond \triangle$ sbcC $\quad \mathrm{X}$ addA5 addB72

\section{$\bigcirc s b c C$ addA5 addB72}

\section{Figure 2}

Survival of Bacillus subtilis wild type or of mutant cells after addition of different doses of MMC for 20 min. The strains used are indicated by the relevant genotype. At least three independent experiments were performed, bars denote standard deviations.

37]\}, for $20 \mathrm{~min}$, followed by plating on normal LB plates, the survival rate was strongly reduced compared to wild type cells (Fig. 2, $13.1 \%$ or $5.6 \%$ survival compared with $50 \%$ or $28 \%$, respectively). Microscopic analysis of MMC-treated cells did not show any different morphologies between wild type and mutant strains, like exponentially growing cells, MMC-treated cells were still present as chains of cells, in which individual cells were elongated compared to the non-treated cells. To avoid any complication with the induction of prophages after DNA damage, the $s b c C$ deletion was moved into strain YB886 that is cured of all inducible prophages [38]. The $s b c \mathrm{C}$ deletion strain formed fewer and smaller colonies on $125 \mathrm{ng} / \mathrm{ml}$ of MMC than wild type cells $\left(\mathrm{rec}^{+}\right)$growing at $150 \mathrm{ng} / \mathrm{ml}$ (Fig. 3, compare panel "150" with "125" ng/ml). Thus,
SbcC is involved in DNA repair. However, cells carrying a deletion of the recA gene are much more severely affected in this aspect (the latter cells were unable to survive a challenge with $50 \mathrm{ng} / \mathrm{ml}$, and could not efficiently grow on 3 $\mathrm{ng} / \mathrm{ml}$, Fig. 3). To test whether the loss of SbcC affects DSB repair, cells were exposed to $\gamma$-irradiation. As shown in Fig. $4 \mathrm{~A}$, the $s b c \mathrm{C}$ deletion strain was marginally, but significantly, impaired in the survival of 50 to 150 Gy (note the log scale-plotting of Fig. 4). However, the true importance of SbcC in DNA repair is masked by the action of other proteins, as will become apparent below.

\section{Genetic interactions of sbcC}

To gain further insight into the involvement of $\mathrm{SbcC}$ in DNA repair, double mutant strains were constructed in 


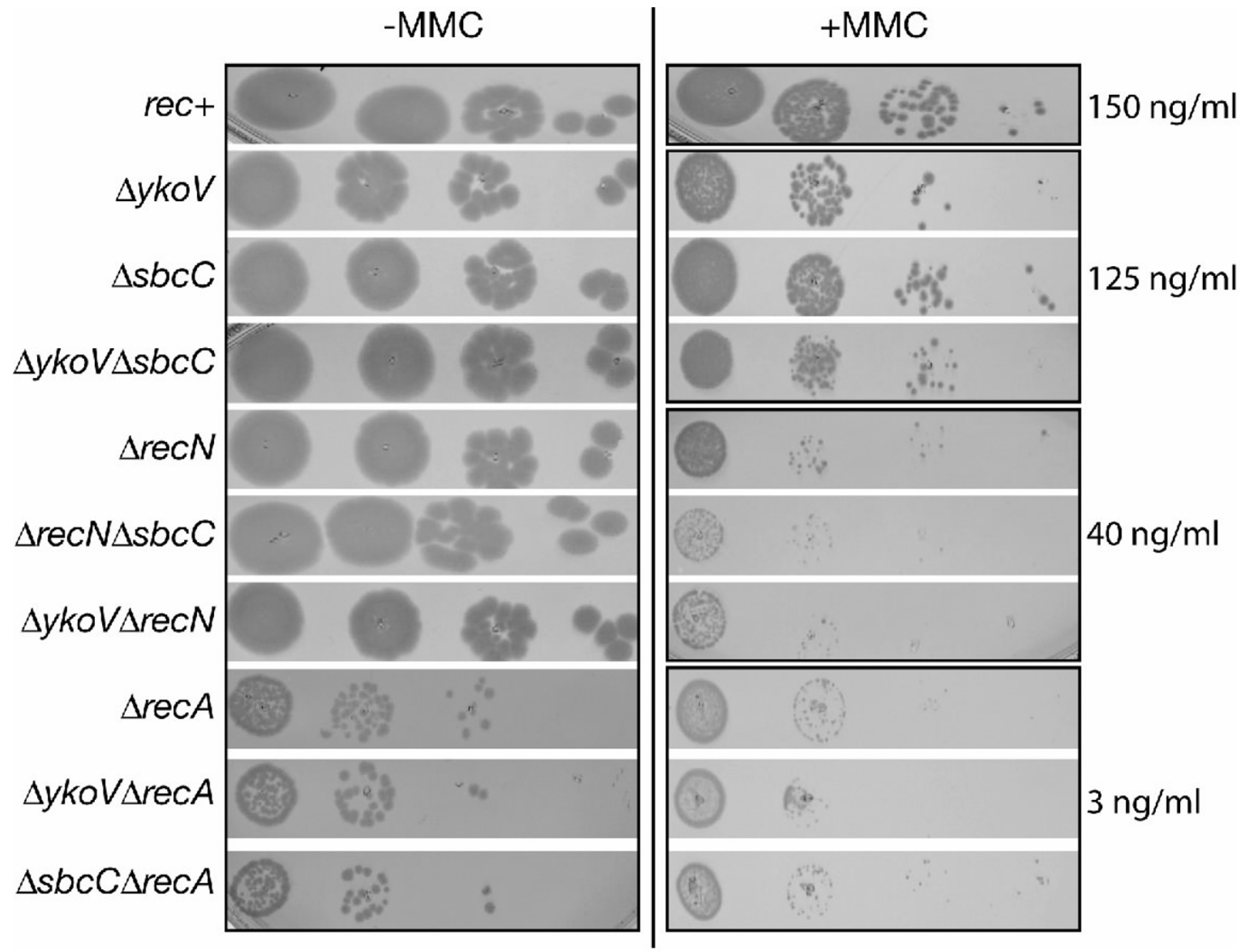

Figure 3

DNA repair sensitivity of exponential-phase $\Delta s b c C$ and $\Delta y k o V$ mutants to the killing action of MMC. The strains used are indicated by the relevant genotype. Serial dilutions of a culture of each strain were plated in selective medium containing the indicated concentration of MMC. Wild type cells were exposed to $150 \mathrm{ng} / \mathrm{ml}, \Delta s b c C, \Delta y k o V$ or $\Delta s b c C \Delta y k o V$ to I $25 \mathrm{ng} / \mathrm{ml}, \Delta r e c N$, $\Delta s b c C \Delta r e c N$ or $\Delta y k o V \Delta r e c N$ to $40 \mathrm{ng} / \mathrm{ml}$ and $\Delta r e c A, \Delta y k o V \Delta r e c A$ or $\Delta s b c C \Delta r e c A$ were exposed to $3 \mathrm{ng} / \mathrm{ml}$ of $\mathrm{MMC}$. At least three independent experiments were performed and one of them is presented.

the prophage-free YB886 background, and their survival rates were compared with those of wild type cells, of a recN deletion $(\Delta r e c N)$ strain, of a $y k o V$ (encodes the B. subtilis Ku protein) deletion strain or of $\Delta r e c A$ cells. The deletion of $s b c C, y k o V$ or $s b c C$ and $y k o V$ did not alter the growth rate of the culture compared with wild type cells, similar to $s b c \mathrm{C} r e c \mathrm{~N}$ or $y k o V \operatorname{rec} N$ mutant cells. Contrarily, recA mutant cells show a strong reduction in growth and plating efficiency [39]. When exponentially growing wild type or mutant cells were exposed to MMC, the strains could be grouped into three different classes, moderately/very/ extremely sensitive to MMC.
Figure 3 shows the concentrations of MMC that affected the plating efficiency of $s b c C$, $\operatorname{rec} \mathrm{N}$, or $\operatorname{rec} A$ mutant cells, respectively. $\mathrm{SbcC}$ or $y k o \mathrm{~V}$ mutant cells and the double $s b c C y k o V$ mutant strain were moderately sensitive to $\mathrm{MMC}$, with a growth defect at $150 \mathrm{ng} / \mathrm{ml}$ and a moderate sensitivity in the presence of $125 \mathrm{ng} / \mathrm{ml}$ of MMC. In contrast, the growth of the wild type was unaffected by the presence of $150 \mathrm{ng} / \mathrm{ml}$ of MMC (Fig. 3), but survival was impaired in the presence of $175 \mathrm{ng} / \mathrm{ml}$ (data not shown, [8]). The $\Delta \operatorname{rec} N$ strain was sensitive to $40 \mathrm{ng} / \mathrm{ml}$ of $\mathrm{MMC}$, and the double $\Delta s b c C \Delta r e c N$ or $\Delta y k o V \Delta r e c N$ strains were considerably more sensitive than the single $\Delta r e c N$ mutant 


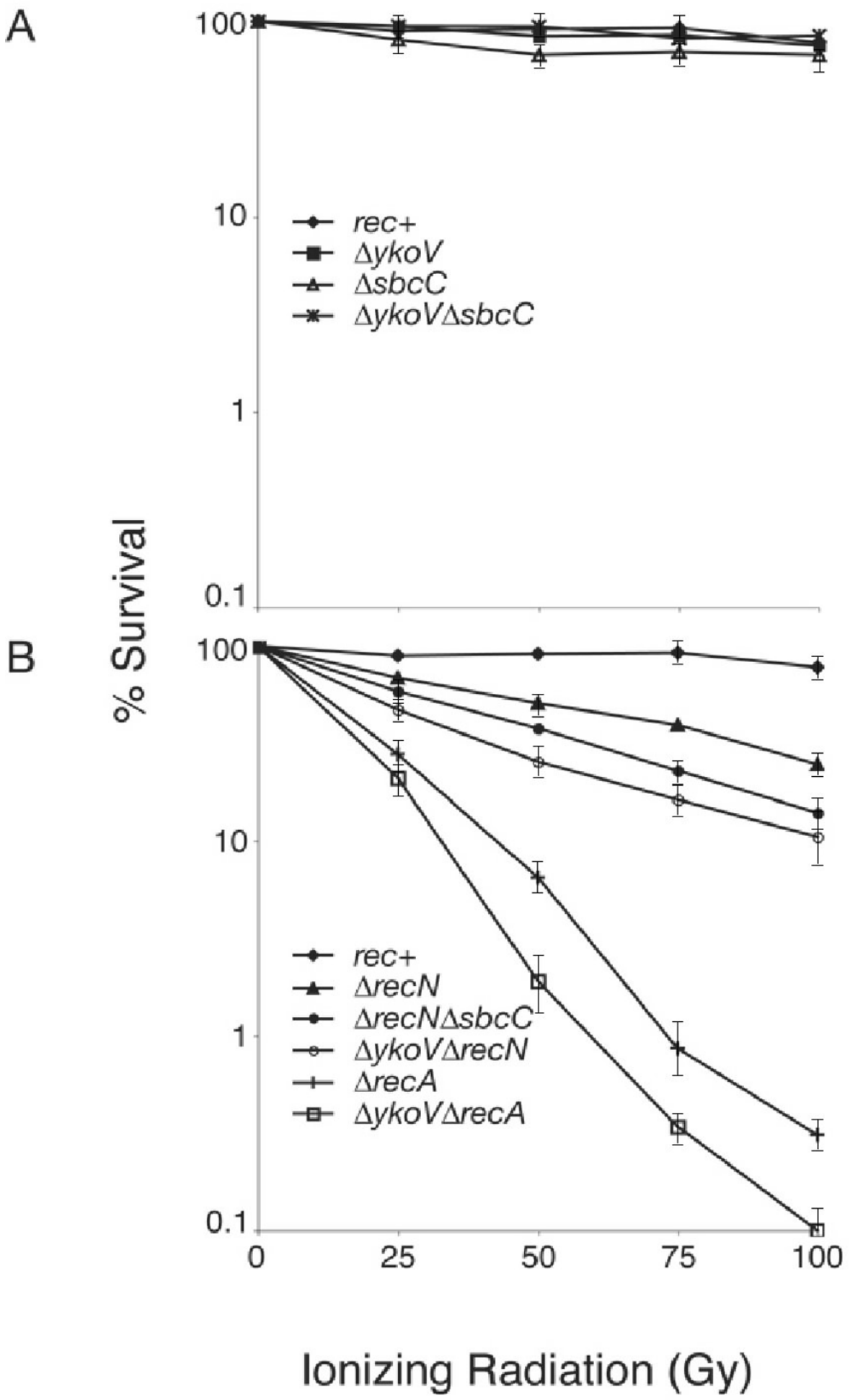

Figure 4

DNA repair sensitivity to $\gamma$-radiation of wild type $\left(\mathrm{rec}^{+}\right)$or of mutant cells grown to stationary-phase. Wild type cells and their isogenic derivatives ( $\Delta s b c C, \Delta y k o V, \Delta s b c C \Delta y k o V, \Delta r e c N, \Delta s b c C \Delta r e c N, \Delta y k o V \Delta r e c N, \Delta r e c A, \Delta y k o V \Delta r e c A$ or $\Delta s b c C \Delta r e c A)$ were exposed to different doses of $\gamma$-radiation. At least three independent experiments were performed, bars denote standard deviations. 
(Fig. 3). The $\Delta r e c N$ strain showed confluent growth at the $10^{-2}$ dilution ( $2^{\text {nd }}$ row) and about 50 microcolonies at the $10^{-3}$ dilution ( $3^{\text {rd }}$ row), whereas the double $\Delta s b c \mathrm{C} \Delta r e c \mathrm{~N}$ or $\Delta y k o V \Delta r e c N$ strains neither showed confluent growth at the $10^{-2}$ dilution, nor microcolonies at the higher dilution. The higher sensitivity of the double mutant strains can be considered a non-epistatic interaction, suggesting that SbcC acts on a DNA repair pathway different from RecN.

One pathway of DNA repair via HR in E. coli involves the RecBCD complex, whose analog in B. subtilis is the AddAB complex $[40,41]$. The survival rate after $M M C$ treatment was reduced in $a d d A B$ mutant cells (29\% or $12 \%, 50$ or $100 \mathrm{ng} / \mathrm{ml}$ of MMC), compared to wild type cells (Fig. 2). However, addAB sbcC mutant cells were more severely affected in the survival test compared with the single mutants (Fig. 2). Therefore, SbcC is also not epistatic with AddAB. We also performed similar experiments using bleomycin that induces DSBs, which yielded similar results (data not shown).

To substantiate these interactions, and to test for sensitivity to DNA damage using another method, stationary phase cultures of wild type or of mutant cells were exposed to ionizing radiation. Wild type, $\Delta s b c C, \Delta y k o V$, or $\Delta s b c C \Delta y k o V$ cells exhibited significant resistance to irradiation up to a dose of $100 \mathrm{~Gy}$ (Fig. 4A). At higher doses, the lethal dose leaving 50\% survivors $\left(\mathrm{LD}_{50}\right)$ was $147 \mathrm{~Gy}$ for wild type cells, $\sim 140 \mathrm{~Gy}$ for $\Delta y k o V$ cells, $\sim 128$ Gy for $\Delta s b c C$ cells, and $\sim 130$ Gy for $\Delta s b c C \Delta y k o V$ double mutant cells. This finding differs from previous work reporting that the $\mathrm{LD}_{50}$ is $\sim 180 \mathrm{~Gy}$ for wild type and $\sim 73 \mathrm{~Gy}$ for the $\Delta y k o V$ strain [4]. It is possible and even likely that this discrepancy is due to different strain backgrounds, i.e. the presence of naturally inducible prophages in the strains used in the cited work. Additionally, differing numbers of spores formed by the two different parent strains could account for the discrepancy, because Bs-Ku plays an important role in DNA repair in spores [42].

The $\Delta r e c N$ strain was very sensitive to $\gamma$-radiation, with a $\mathrm{LD}_{50}$ of $92 \mathrm{~Gy}$. However, the $\mathrm{LD}_{50}$ was $61 \mathrm{~Gy}$ for the $\Delta s b c \mathrm{C} \Delta r e c \mathrm{~N}$ strain, and $\sim 40$ Gy for the $\Delta y k o V \Delta r e c N$ strain (Fig. 4B), representing a 1.5 -fold and 2.3-fold increase in the sensitivity of the double mutant strains compared to the $\Delta r e c N$ strain. These results confirm that $s c b C$ and $r e c N$ or $y k o V$ and $r e c N$ show a non-epistatic interaction.

The $\Delta r e c A$ strain was highly sensitive to $\gamma$-radiation, with a $\mathrm{LD}_{50}$ of $20 \mathrm{~Gy}$ (Fig. $4 \mathrm{~B}$ ), however, the $\mathrm{LD}_{50}$ of the double $\Delta y k o V \Delta r e c A$ mutant strain was $\sim 16 \mathrm{~Gy}$. The sensitivity of the double mutant strain was clearly higher than that of the already sensitive single mutant and can be considered a non-epistatic interaction, consistent with a previous report [4]. In contrast, the $\Delta s b c C \Delta r e c A$ double mutant strain was as sensitive to gamma irradiation as the recA mutant strain (data not shown, see $\Delta r e c A$ in Fig. 4).

The data show that SbcC plays an important role in DNA inter-strand cross-link repair, and acts in a different pathway than AddAB or RecN, while it is epistatic with RecA. Its importance becomes clearer in the $\Delta r e c N$ background, which is also true for the function of Bs-Ku protein. The data also suggest that HR is the main repair system for DNA inter-strand cross-links and DSBs in B. subtilis, while NHEJ constitutes a backup system that is required in the absence of HR repair.

\section{SbcC forms defined foci on the nucleoids upon induction of DNA DSBs}

To visualize the subcellular localization of B. subtilis SbcC, we created a C-terminal fusions of $s b c C$ to $g f p$ or to $y f p$, ensuring transcription of the downstream genes by an internal xylose-inducible promoter. The SbcC-GFP and SbcC-YFP fusions were fully functional as judged by their ability to survive a challenge with MMC like wild type cells (Fig. 2, and data not shown). 30 min after the addition of MMC, nucleoids adopted a somewhat more condensed morphology and appeared to fuse, because only $4 \%$ of MMC treated cells contained two nucleoids, in spite of their increased cell length (compare Fig. 5A with 5C), whereas $21 \%$ of exponentially growing cells contain two nucleoids rather than one. 2 hours after induction of DNA damage, cells were highly elongated, and frequently contained nucleoids with abnormal morphology (Fig. 5D and 5E). Exponential growth resumed about 3 hours after addition of 50 to $100 \mathrm{ng} / \mathrm{ml}$ of MMC.

In exponentially growing cells, extremely faint fluorescence above background was detectable for SbcC-YFP, which appeared to be present throughout the cells (Fig. $5 \mathrm{~A})$. However, in $2 \%$ of the cells, discrete SbcC-YFP foci were visible (Fig. 5B). Interestingly, the number of SbcCYFP foci increased as soon as $30 \mathrm{~min}$ after addition of MMC (Fig. 5C, in 5\% of the cells, $>250$ cells analyzed), and was highest 2 hours after addition of MMC (40\% of the cells containing foci, $>300$ cells counted, Fig. 5D). Exposure times of $3 \mathrm{~s}$ were necessary to visualize SbcC-YFP foci because signal intensity was very weak (exposure of more than $3 \mathrm{~s}$ did not increase signal intensity, as is the case for any GFP fusion analyzed so far with our technical setup). About $90 \%$ of the SbcC-YFP foci were located on the nucleoids, showing that the foci were generally associated with DNA. To investigate if SbcC-YFP foci are only induced through inter-strand cross links, or also through DSBs, exponentially growing cells were irradiated with 12 Gy of hard X-rays, which is a dose that induces DSBs but does not reduce viability of $B$. subtilis cells. Similar to the addition of MMC, hard X-rays induced fluorescent foci in 
A

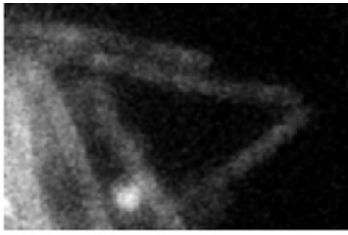

SbcC-YFP

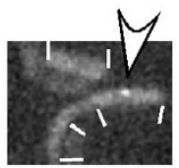

B SbcC-YFP

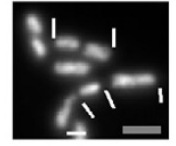

DNA

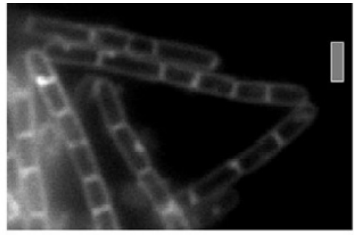

membranes

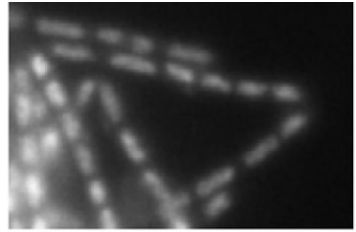

DNA

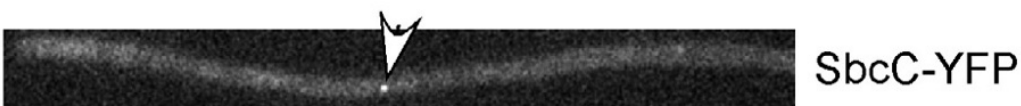

C
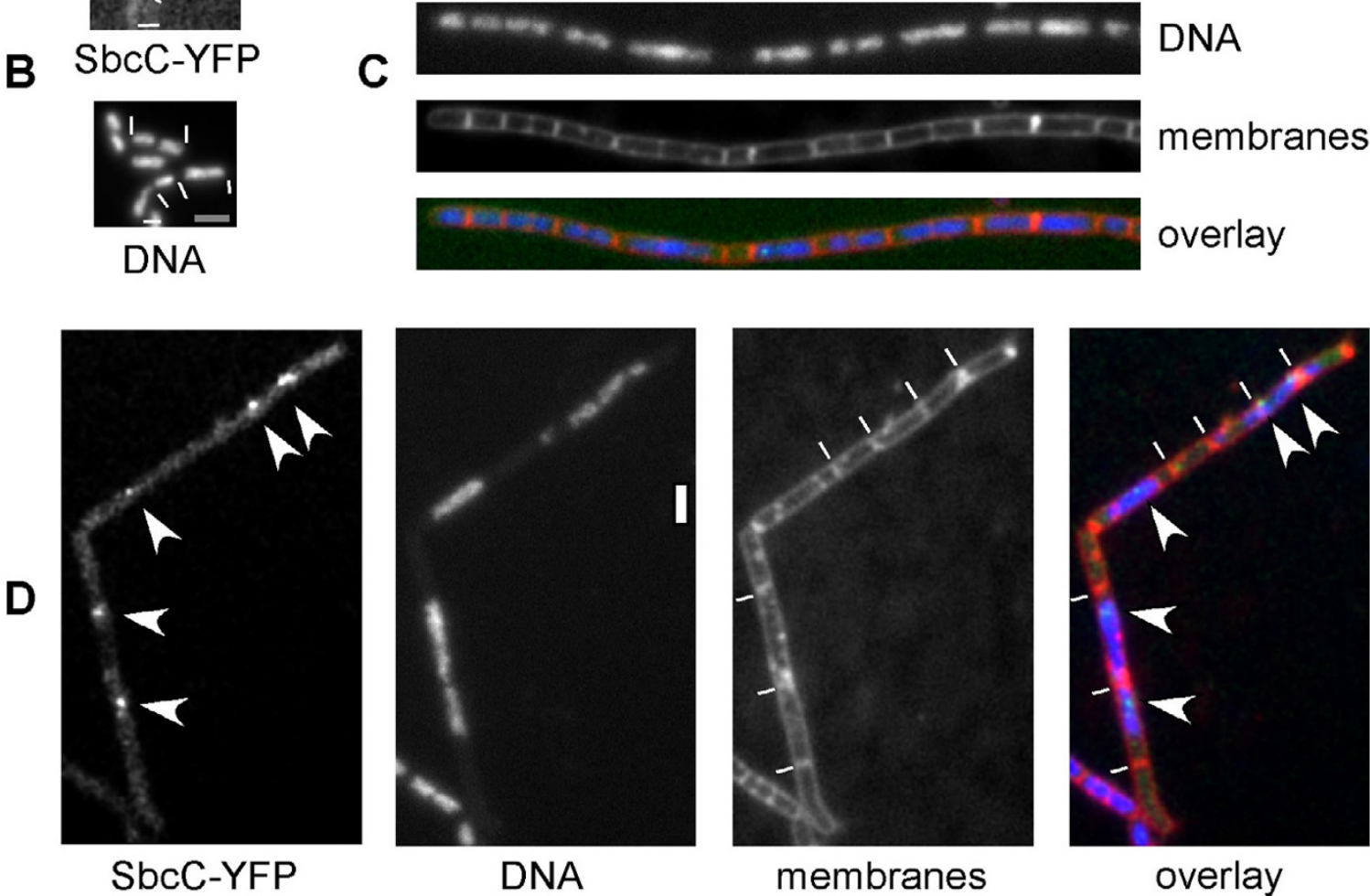

membranes

overlay

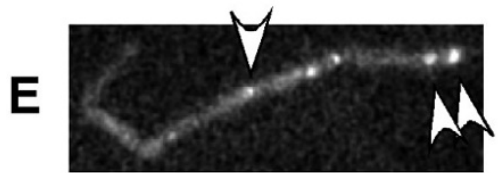

SbcC-YFP

$\mathbf{F}$

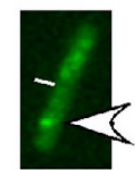

SbcC- DnaX- overlay YFP CFP

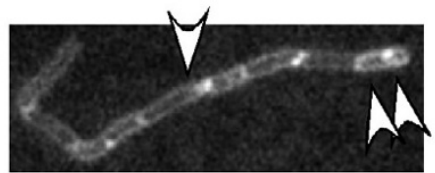

membranes

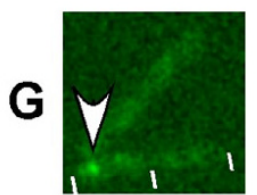

SbcC-YFP

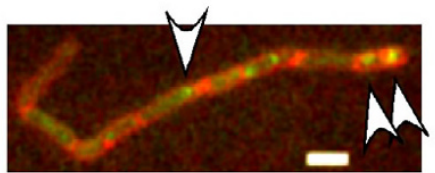

overlay

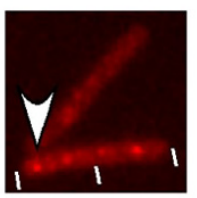

DnaX-CFP

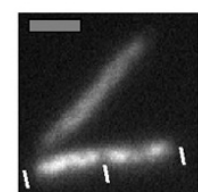

DNA

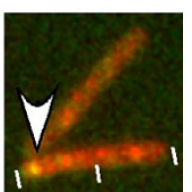

overlay

Figure 5

Fluorescence microscopy of Bacillus subtilis cells. A-B) Strain JN6 (sbcC-yfp) growing exponentially, or C) 30 min or D) I20 min after addition of $50 \mathrm{ng} / \mathrm{ml}$ of MMC, or E) $120 \mathrm{~min}$ after addition of $200 \mathrm{ng} / \mathrm{ml}$ of MMC. F-G) Strain JM6I (dnaX-cfp, sbcC-yfp) I 20 min after addition of MMC. White arrowheads indicate the localization of SbcC-YFP and co-localization of the protein fusions. White lines indicate septa between cells. White bars $2 \mu \mathrm{m}$. 


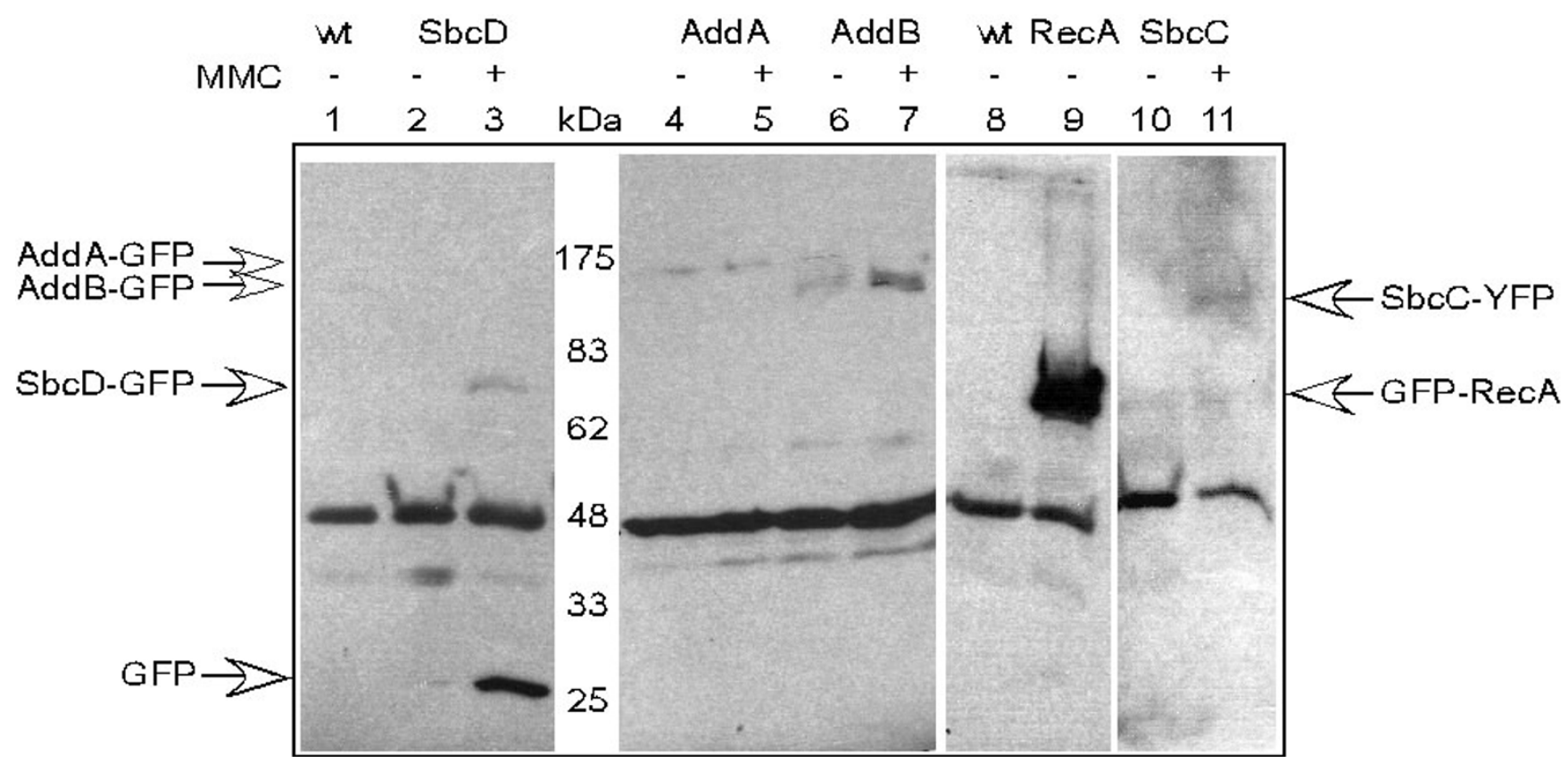

\section{Figure 6}

Western blot analysis of B. subtilis cells using anti-GFP antiserum. Lane I: PY79, exponential growth, lanes 2 and 3: JN4 (sbcD$g f P)$, lane 2 exponential growth, lane 3 one hour after addition of MMC (I00 ng/ml), lanes 4 and 5: JN7 (addA-gfp), lane 4 exponential growth, lane 5 one hour after addition of MMC, lanes 6 and 7: JM4I (addB-yfp), lane 6 exponential growth, lane 7 one hour after addition of MMC, lane 8: PY79, lane 9: DK39 (gfp-recA), lanes 10 and II: JN6 (sbcC-yfp), lane 10 exponential growth, lane II one hour after addition of MMC. The same amount of protein was loaded in each lane. Arrows indicate the position of fusion proteins and of free GFP. AddA-GFP: 169 kDA, AddB-YFP: 162 kDa, SbcC-YFP: I53 kDa, SbcD-GFP: 7I kDa, GFP-

RecA: $66 \mathrm{kDa}$, GFP: $28 \mathrm{kDa}$. Note that the antiserum strongly cross reacts with a protein of about $48 \mathrm{kDa}$.

30 to $35 \%$ of the cells (data not shown), showing that SbcC foci are also formed after generation of radiationinduced DSBs.

To rule out that the formation of SbcC foci is caused by an artefact, we performed Western Blot analysis of cells growing in the absence or presence of MMC. Fig. 6 shows that the synthesis of full length SbcC-YFP is induced after administration of DNA damage (lane 11), while it is undetectable in cells growing in the absence of damage (lane 10) or in cells lacking the YFP fusion (lane 8), in agreement with the cell biological data. Similar experiments with the same anti GFP serum showed much stronger signals for GFP-RecA (lane 9), or for various other GFP fusions (e.g. BsSMC-GFP or Spo0J-GFP, data not shown) that are not highly expressed in growing cells $[43,44]$, suggesting that SbcC is a poorly expressed protein in growing cells.

After addition of $50 \mathrm{ng} / \mathrm{ml}$ of MMC, only one SbcC-YFP focus was detectable in $34 \%$ of the cells, while $6 \%$ of the cells contained 2 foci, and $60 \%$ no visible focus. Interestingly, the number of cells containing foci and the number of foci per cell did not vary significantly between sublethal and lethal doses of MMC (50 to 200 ng/ml, compare Fig. $5 \mathrm{D}$ and 5E).

\section{SbcC centers mostly co-localize with the replication machinery}

Inter-strand cross-links block the progression of the replication fork. Also, DSBs can arise at the replication fork, when DNA lesions hinder the progression of the replicative polymerase complex. To test whether $\mathrm{SbcC}$ acts at the replication fork, or also at other sites within the cell, we created a dually labelled strain, expressing DnaX-CFP (the tau subunit of DNA polymerase III) and SbcC-YFP. It was technically challenging to obtain clear CFP and YFP signals within the same cell, mostly due to low SbcC-YFP signal intensity. However, we were able to obtain clear signals in both channels for 32 cells (out of 300 cells analyzed). Interestingly, when inter strand cross links were induced, 22 of the SbcC-YFP foci co-localized with DnaXCFP (Fig. 5F-G), and 4 foci were in close proximity $(<0.3$ $\mu \mathrm{m})$, while 6 of the foci were clearly separate $(>0.3 \mu \mathrm{m})$. Thus, SbcC foci mostly co-localize with the replication machinery. 


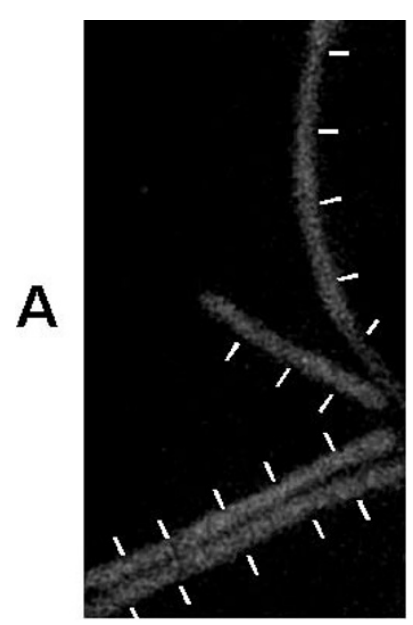

AddA-GFP

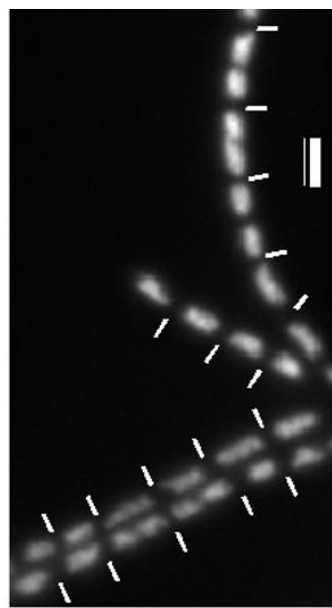

DNA

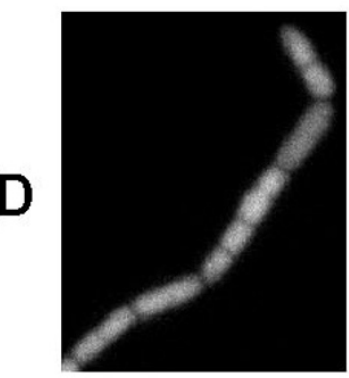

SbcD-GFP

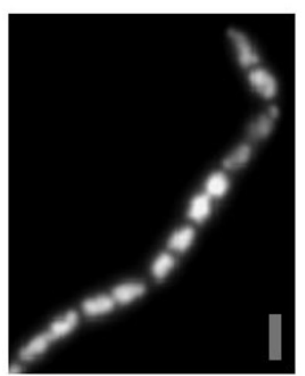

DNA
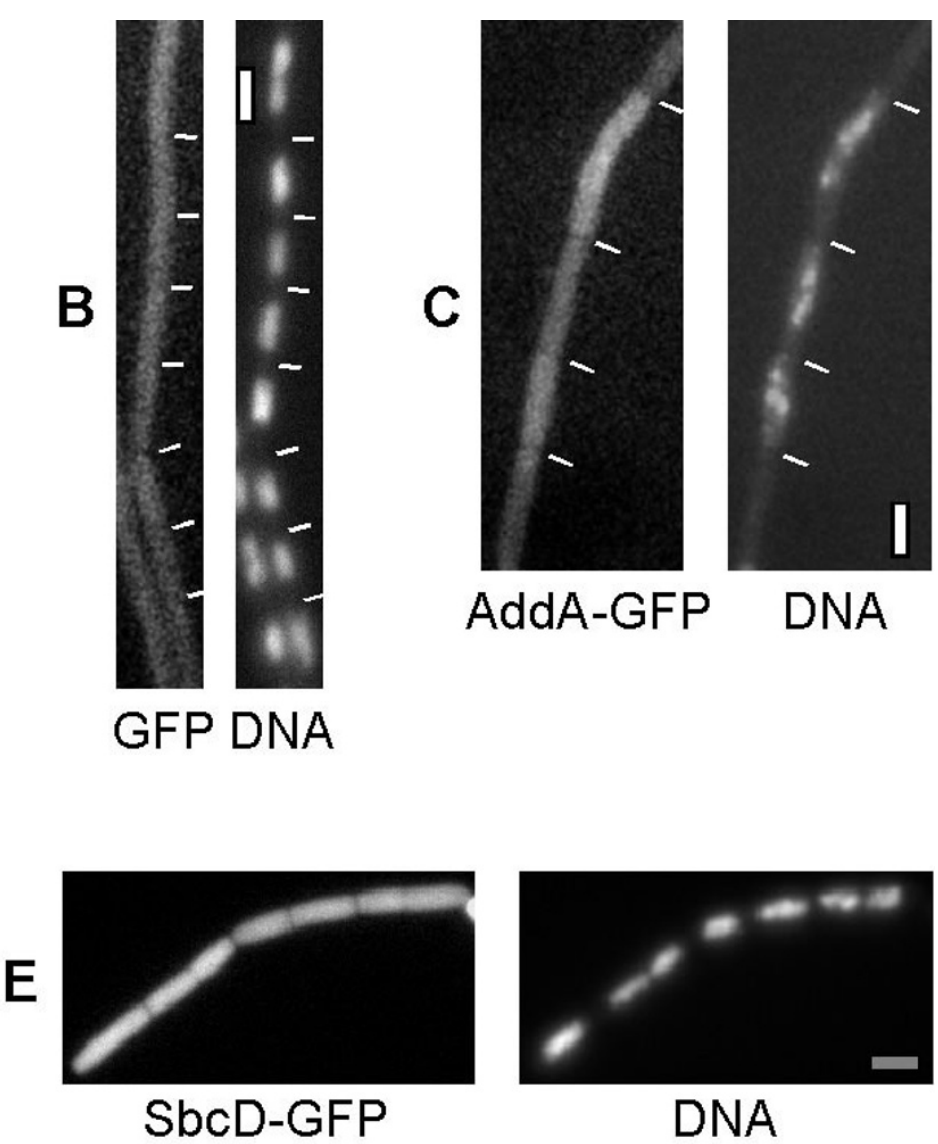

DNA

\section{Figure 7}

Fluorescence microscopy of Bacillus subtilis cells. A-C) Strain JN7 (addA-gfp) growing exponentially (A), or B) 30 min or C) I20 min after addition of $50 \mathrm{ng} / \mathrm{ml}$ MMC, D-E) strain JN4 (sbcD-gfp) growing exponentially (D), or 60 min after addition of MMC (E). White bars $2 \mu \mathrm{m}$.

It is interesting to note that the pattern of localization of the replication machinery was altered upon induction of DNA damage. $85 \%$ of exponentially growing cells contained one single or two bipolar DnaX-CFP foci (and 15\% no signal), whereas after addition of $\mathrm{MMC}$, only $62 \%$ of the cells contained this proper localization of the replisome, and $23 \%$ of the cells contained signals at various places in the cell (15\% did not show any signal, data not shown). Additionally, $66 \%$ of exponentially growing cells contained one central DnaX-CFP focus, and 19\% two bipolar foci ( $15 \%$ did not contain a signal), whereas after induction of damage, a higher proportion of the cells $(40 \%)$ contained two or more foci, rather than one $(45 \%$, $15 \%$ did not contain any focus). Thus, the specific localization of the replication factory becomes more random during DNA repair, and, apparently, replication forks separate (and/or replication reinitiates in the absence of cell division) in a considerable fraction of the cells. Our finding that SbcC forms no more than 1 or 2 foci after induc- tion of DNA damage agrees with the finding that SbcC generally colocalizes with the replication machinery.

\section{The AddAB complex localizes throughout the cells}

To visualize the other repair proteins from the add operon, we generated C-terminal fusions of $a d d A$, of $a d d B$ or of $s b c D$ to GFP, or to YFP, such that addA-gfp, or $a d d B-\gamma f p$, or $s b c D$-gfp were integrated at the corresponding original locus within the $a d d A B$ operon. AddA-GFP or AddB-YFP fusion proteins were fully functional, as judged by their ability to survive MMC treatment like wild type cells (data not shown). In exponentially growing cells, weak background fluorescence was detectable throughout the cells for AddA-GFP or for AddB-YFP (Fig. 7A, and data not shown). Between $30 \mathrm{~min}$ and 2 hours after addition of $\mathrm{MMC}$, fluorescence increased throughout the cells for both fusions, without any apparent accumulation within the cell (Fig. 7B and 7C). Fig. 6 shows that only full-length fusion proteins were produced (lanes $4-7$ ) at a very low 
level, and at least AddB-YFP clearly accumulated after addition of MMC (compare lane 7 with lane 6). Thus, the AddAB complex does not appear to be specifically associated with the nucleoid, and does not accumulate as discrete foci after induction of DNA damage. Possibly, only few AddAB molecules are recruited to sites of DNA repair. In cells expressing SbcD-GFP, fluorescence was detected throughout the cells, and increased in level after addition of MMC (Fig. 7D and 7E), however, much more free GFP than SbcD-GFP fusion protein was apparent in the cells (Fig. 6, lane 3). These results show that the SbcD-GFP fusion is proteolytically cleaved (the first such event we have found so far), such that freely diffusing GFP is masking the localization of SbcD-GFP. Like SbcC-YFP, the signal of SbcD-GFP/GFP increased after addition of MMC (Fig. 6, compare lane 3 with lane 2).

\section{Discussion}

Our work shows that the bacterial counterpart of the eukaryotic Rad50 protein, $\mathrm{SbcC}$, confers an important function in the repair of inter strand cross links in DNA caused by MMC, and plays a role in the repair of DSBs (caused by gamma irradiation), most likely in the context of repair of collapsed replication forks. The deletion of $s b c C$ led to a considerable sensitivity to DNA damage. However, the loss of SbcC in a recN or in an addAB mutant background increased the sensitivity to DNA damage of the very sensitive $r e c N$ or $a d d A B$ single mutant strains. Contrarily, the loss of SbcC in recA mutant cells did not increase the extreme sensitivity of the single recA mutant strain, showing that SbcC is epistatic with RecA, but not with RecN or with AddAB. These experiments suggest that SbcC acts on DNA repair via homologous recombination (HR), and show that it confers a function distinct from RecN or from AddAB.

Interestingly, like $\mathrm{SbcC}$, Bs-Ku protein was non-epistatic with RecN or AddAB, and the loss of BS-Ku in recN mutant cells led to a similar increase in sensitivity towards DNA damage than the loss of $\mathrm{SbcC}$ in this mutant background. Because the loss of Bs-Ku protein in a $s b c \mathrm{C}$ mutant strain did not increase the mild sensitivity of the $s b c C$ single mutant strain, and vice versa, it is possible that $\mathrm{SbcC}$ may also play a role in NHEJ. Possibly, upon encountering DNA ends, the SbcC alone, or in concert with the Bs-Ku protein, might tether DNA ends together, which are finally joint by a DNA ligase [45]. Indeed, several reports have supported a dual function of the eukaryotic Rad50 complex in DNA repair via HR as well as in NHEJ. However, many more experiments are required to establish a connection between SbcC and NHEJ, and the finding that $\mathrm{Bs}-\mathrm{Ku}$ is non epistatic with RecA, in contrast to SbcC, shows that the main function of SbcC does not lie in NHEJ, but rather in HR.
It is clear from our work that repair of DSBs and of interstrand cross-links via HR plays a major role in B. subtilis cells, because the loss of proteins participating in HR [e.g. RecN, AddAB] caused severe sensitivity to radiationinduced DNA damage, while the loss of Bs-Ku led to moderate sensitivity. The activity of Bs-Ku became important in cells defective in repair via HR, indicating that NHEJ serves as a back up system to repair DSBs that can not be fixed via HR, e.g. non-duplicated chromosome regions, for which no sister chromosome is present to set up HR. Interestingly, it has recently been shown that Bs-Ku and DNA ligase encoded by $y k o U$ play an important role in resistance of spores to killing through dry heat, a treatment that introduces breaks into DNA [42]. Because the spore contains only a single chromosome, DSBs can not be repaired via HR, but only through NHEJ, which is also important for DSB repair during cell cycle exit in all other types of cells. However, our results show that Bs-Ku also performs a function in DNA repair in exponentially growing cells, because the absence of Bs-Ku leads to mild but noticeable sensitivity towards MMC.

A further major finding of this work that provides a clue as to the function of $\mathrm{SbcC}$ is the observation that $\mathrm{SbcC}$ transiently assembles into discrete subcellular centers on the nucleoids after the induction of inter-strand crosslinks and of DSBs. In growing cells, SbcC was mostly dispersed throughout the cells, while the accumulation of SbcC was observed as early as $30 \mathrm{~min}$ after induction of DNA damage, its main accumulation occurring between 1 and 2 hours post induction. Thereafter, the SbcC-GFP foci dissipated, concomitant with the resumption of growth. Intriguingly, $\mathrm{SbcC}$ assembled most frequently at the replication machinery, suggesting that $\mathrm{SbcC}$ acts on DNA damage occurring at the replication forks, which can block replication (e.g. cross links or base adducts), or lead to fork collapse (e.g. when forks run into ssDNA gaps) [46]. However, at low frequency, replication forks collapse in non-stressed exponentially growing cells [47]. Consistent with this, we also observed $\mathrm{SbcC}$ foci at low frequency in exponentially growing cells in the absence of externally induced damage. The E. coli SbcCD complex, which shows some similar in vitro activities than the Rad50 complex [48], has been shown to be involved in the cleavage of DNA hairpins that can occur at the replication forks [24]. Possibly, this is one of the specific roles SbcC confers during replication, and at stalled or collapsed replication forks, SbcC could be involved in replication restart through HR, and/or removal of inter-strand cross-links.

Recently, we have shown that RecN assembles at defined DSBs or at random DNA lesions as early as $15 \mathrm{~min}$, while RecO and RecA are recruited 30-60 min after induction of DSBs [31,32]. DSB repair appears to last for about 3 hours, and RecF protein is recruited to DSBs after $90 \mathrm{~min}$, 
Table I: Strains used in this work

\begin{tabular}{|c|c|c|}
\hline Strain & genotype & reference \\
\hline PY79 & & {$[58]$} \\
\hline JN4 & $s b c D-g f p$ & this work \\
\hline JN6 & $s b c C-y f p$ & this work \\
\hline JN7 & addA-gfp & this work \\
\hline JM4I & $a d d B-y f p$ & this work \\
\hline JM42 & $s b c C:: c m$ & this work \\
\hline $\mathrm{JHI}$ & $y k o V:: c m$ & this work \\
\hline JM6I & $d n a X-c f p, s b c C-y f p$ & this work \\
\hline YB886 & $\operatorname{trp} C 2$ metB5 amyE sigB37 xin- I attSP $\beta$ & {$[38]$} \\
\hline BGI89 & addA5 addB72 & {$[54]$} \\
\hline BG277 & recN::cm & {$[59]$} \\
\hline BG 190 & recA::cm & {$[55]$} \\
\hline BG809 & ykoV:::cm & this work \\
\hline BG8II & $s b c C:: \mathrm{cm}$ & this work \\
\hline BG843 & ykoV::tet, recN::cm & this work \\
\hline BG849 & ykoV::tet, recA::cm & this work \\
\hline BG847 & ykoV::cm, sbcC::tet & this work \\
\hline BG845 & sbcC::tet, recN:: cm & this work \\
\hline DK39 & $g f p-r e c A$ & {$[32]$} \\
\hline
\end{tabular}

Note that BG strains are isogenic with the YB886 wild type strain (used for survival studies in Fig. 2 and 3), while the other strains are isogenic with the PY79 wild type strain (used for Fig. I and localization studies).

thus representing a late-recruited protein. $\operatorname{RecN}$ binds to ssDNA at an internal site, and gathers the 3'-hydroxyl ssDNA ends in vitro [8]. These finding are consistent with the idea that RecN, like eukaryotic Rad50 [49], might be an early sensor of sites of DNA damage on replicating and non-replicating chromosomes [50]. The cytological data presented here provide a clear distinction between the functions of SbcC and of RecN, because RecN is generally not associated with the replication machinery [32], and appears to act as a nucleation factor of DNA repair centers away from the replication machinery, while SbcC appears to assemble at DNA damage occurring at the replication factory. A different function for SbcC and RecN - dependent on whether DNA damage occurs at the replication fork or elsewhere on the nucleoid - can explain why SbcC-YFP foci are only observed in about $40 \%$ of the cells after induction of random DNA damage (this work), while RecN-YFP foci occur in about $70 \%$ of the cells (but not in all cells) under these conditions [31].

SbcC and RecN belong to the SMC protein family, whose members are key players in various chromosome dynamics. Our report establishes that these two B. subtilis proteins SMC like proteins confer important yet distinct functions in the repair of DNA base modifications, of DNA inter-strand cross-links and of DSBs. It will be interesting to elucidate the molecular basis of their different modes of action.

\section{Methods \\ Bacterial strains and media}

E. coli XL1-Blue (Stratagene) harbouring plasmids were grown in Luria-Bertani (LB) rich medium supplemented with $50 \mu \mathrm{g} / \mathrm{ml}$ ampicillin. B. subtilis strains were grown in LB rich medium, and when necessary with appropriate antibiotics. For microscopy, cells were grown in $S 7_{50}$ defined medium [51]. All B. subtilis strains used in this study are listed in Table 1.

\section{Construction of plasmids and strains}

All CFP, GFP or YFP fusions were done by PCR amplification of the 3' regions of each gene, and cloning into a vector containing a C-terminal $c f p$, $g f p$ or $\gamma f p$ gene. All fusion vectors contained inducible promoters ensuring transcription of downstream genes. To create a C-terminal fusions of AddA and of SbcD to GFP, the corresponding 3 ' regions (about $500 \mathrm{bp)}$ were PCR amplified (AddA-GFP 5'ATTCGGGCCCAGCTGAGCTGGACCTAC-3' and 5'-TCGGAATTCACCACCGCCT-AATGTCAGAATGTGCCC-3', SbcD-GFP 5'-TCGGAATTCACCGCCTTTCGCA-TCCTCCTCTTCAAC-3' and 5'-ATTCGGGCCCTTTGCATCGCCCGCAAACG-3') and were cloned into ApaI and EcoRI sites of pSG1164 [52], giving rise to plasmids pA1164 and pD1164, respectively. The 3' region of yirY $(s b c C)$ (primers 5'-ATTCAAGCTTGCAAA-CTTGAAAACGAG-3' and 5'- TCGGAATTCACCACCGCCCATCAACTCAAGTGATAC-CCG- 3') was cloned into pSG1187 (Cterminal $\gamma f p$ ) using HindIII and EcoRI sites, giving rise to plasmid pC87. This plasmid could not be integrated into the $B$. subtilis chromosome because of the downstream yisB gene. An EcoRI SpeI fragment from pC87 containing the 3'yirY-yfp fusion was cloned into pSG1164, giving rise to pC87xyl. The 3' region of $a d d B$ (primers 5'-CCATCGATACCGCCTCCGGAATGTTCATTGCCATC -3' and 5'TTGATTTATCGATTACACATTC -3') was cloned into pMutinYFP (containing an IPTG inducible promoter for downstream genes) using ClaI, giving rise to plasmid $\mathrm{pBy}$. All plasmids were transformed into wild type (PY79) $B$. subtilis cells selecting for chloramphenicol $(\mathrm{Cm})$ resistance $(5 \mu \mathrm{g} / \mathrm{ml})$. All fluorescent tag vectors were integrated into the $B$. subtilis chromosome via single crossover integration, which was verified by PCR and Western Blot analysis.

For disruption of $s b c C$, a 1000 bp internal fragment of $s b c C$ was PCR amplified (primers 5'-ACATGCATGCAATCTGCCCTTCGCCTCTTG-3' and 5'-TCATAAGCTT-CAAACAGGAACAGCTTTCACG-3') and was cloned into HindIII and SphI sites of pJQ43 (containing a constitutive promoter for downstream genes) [53], giving rise to plasmid pSbcKO. Single crossover integration of pSbcKO lead to disruption of the $s b c C$ gene $(s b c C:: c m)$ and to the synthesis of a C-terminal truncated SbcC. For the disruption of $y k o V$, a 480 bp internal fragment from $y k o V$ 
was cloned into pSG1164, and the resulting plasmid pykoVKO was transformed into PY79, generating strain JH1 $(y k o V:: \mathrm{cm})$.

The $a d d A B$ sbc $C$ triple mutant strain was generated by transforming addA5 addB72 (collectively termed addAB mutant cells) mutant cells [54] with chromosomal DNA from strain JM42, selecting for Cm resistance. The inactivation of the $\operatorname{rec} \mathrm{N}$ and $r e c A$ genes by a double crossover event was previously described $[41,55]$. To study genetic interactions in a strain freed of inducible prophages (which complicate analysis of DSBs), all deletions were moved into strain YB886 ( $\mathrm{rec}^{+}$control) [38]. The $\Delta s b c \mathrm{C}$ and $\Delta y k o V$ strains were generated by transferring the $s b c C:: \mathrm{cm}$ or $y k o V:: \mathrm{cm}$ allele onto the YB886 strain by a single crossover event. To generate double mutants, the $\mathrm{Cm}$ resistance cassette in $\Delta s b c C$ or $\Delta r e c N$ cells was replaced by tetracycline resistance in vivo by transformation with plasmid pCm::tet (BGSC, Wisconsin, USA). Double mutants were produced by transformation of $\Delta r e c N, \Delta r e c A, \Delta s b c C$ and $\Delta y k o V$ mutant strains with the appropriate chromosomal DNA from other mutant strains.

\section{DNA repair sensitivity studies}

DNA modifications generated by Mitomycin C (MMC) result in the formation of base adducts and inter-strand cross-links, which generate single-strand breaks and DSBs [35-37]. Ionizing radiation ( $\gamma$-rays) leads to the formation of apurinic/apyrimidinic sites and generates nicks and DSB. All survival studies were performed at least 3 times, and were performed in the absence of antibiotics. For sensitivity to MMC assays (Fig. 3), exponentially growing $B$. subtilis cells were obtained by inoculating overnight cultures in fresh LB media and by growing to an $\mathrm{A}_{560 \mathrm{~nm}}$ of 0.4 at $37^{\circ} \mathrm{C}$. Appropriate dilutions $(10 \mu \mathrm{l}$ of serial 10 -fold dilutions, $1 \times 10^{-2}$ to $1 \times 10^{-5}$ ) were spotted onto LB plates supplemented with the indicated concentration of $\mathrm{MMC}$, and were incubated overnight at $37^{\circ} \mathrm{C}$. MMC and all plates used for survival tests were kept in the dark at all times, in order to avoid complications generated by photoadducts.

For ionizing radiation assays (Fig. 4), stationary phase cultures of $B$. subtilis cells were obtained by inoculating overnight cultures in fresh LB media and by growing to an $\mathrm{A}_{560 \mathrm{~nm}}$ of 2 at $37^{\circ} \mathrm{C}$. Irradiation was carried out with ${ }^{137} \mathrm{Cs}$ $\gamma$-rays using a Mark I irradiator (JL Shepard \& Associates) at a dose-rate of $3.7 \mathrm{~Gy} / \mathrm{min}$, without shaking at room temperature, using $50 \mu \mathrm{l}$ of cells from a 100-fold dilution. Appropriate dilutions of irradiated cells were plated, incubated overnight at $37^{\circ} \mathrm{C}$ and colonies were counted from at least three independent experiments.

\section{Western blot analysis}

Western blotting was performed using same amounts of cell extracts, as determined by Bradford tests, using antiserum generated against purified GFP-6-his protein (kind gift from David Rudner, Harvard Medical School).

\section{Image acquisition}

Fluorescence microscopy was performed on an Olympus AX70 microscope. Cells were mounted on agarose pads containing S750 growth medium on object slides. Images were acquired with a digital MircoMax CCD camera; signal intensities and cell length were measured using the Metamorph 4.6 program. DNA was stained with 4',6-diamidino-2-phenylindole (DAPI; final concentration 0.2 $\mathrm{ng} / \mathrm{ml}$ ) and membranes were stained with FM4-64 (Molecular Probes, USA, final concentration $1 \mathrm{nM}$ ).

\section{Authors' contributions}

JM constructed strains and performed fluorescence microscopy, HS constructed strains and carried out sensitivity assays, ST and DK carried out sensitivity assays, MK performed Western blot analyses, JCA and PLG conceived of the study, and participated in its design and coordination. All authors read and approved the final manuscript

\section{Acknowledgements}

We thank Nicole Scherr and Castillo Cózar for valuable technical assistance. This work was partially supported by grants BMC2003-00I50 and BIO200I-4342-E from DGI-MEC to J.C.A and from the Deutsche Forschungsgemeinschaft (Emmy Noether Programm) to P.L.G.

\section{References}

I. Berardini M, Foster PL, Loechler EL: DNA polymerase II (polB) is involved in a new DNA repair pathway for DNA interstrand cross-links in Escherichia coli. J Bacteriol 1999, I 8 I:2878-2882

2. Lieber MR, Ma Y, Pannicke U, Schwarz K: Mechanism and regulation of human non-homologous DNA end-joining. Nat Rev Mol Cell Biol 2003, 4:712-720.

3. Downs JA, Jackson SP: A means to a DNA end: the many roles of Ku. Nat Rev Mol Cell Biol 2004, 5:367-378.

4. Weller GR, Kysela B, Roy R, Tonkin LM, Scanlan E, Della M, Devine SK, Day JP, Wilkinson A, d'Adda di Fagagna F, Devine KM, Bowater RP, Jeggo PA, Jackson SP, Doherty AJ: Identification of a DNA nonhomologous end-joining complex in bacteria. Science 2002, 297:1686-1689.

5. Fernandez S, Ayora S, Alonso JC: Bacillus subtilis homologous recombination: genes and products. Res Microbiol 2000, 1 $51: 48 \mid-486$.

6. Cromie GA, Connelly JC, Leach DR: Recombination at doublestrand breaks and DNA ends: conserved mechanisms from phage to humans. Mol Cell 200 I, 8: I I63-I I74.

7. Paques F, Haber JE: Multiple pathways of recombination induced by double-strand breaks in Saccharomyces cerevisiae. Microbiol Mol Biol Rev 1999, 63:349-404.

8. Sanchez $\mathrm{H}$, Alonso JC: Bacillus subtilis RecN binds and protects 3'-single-stranded DNA extensions in the presence of ATP. Nucleic Acids Res 2005, 33:2343-2350.

9. Kowalczykowski SC, Dixon DA, Eggleston AK, Lauder SD, Rehrauer WM: Biochemistry of homologous recombination in Escherichia coli. Microbiol Rev 1994, 58:40I-465.

10. Bressan DA, Baxter BK, Petrini JH: The Mrell I-Rad50-Xrs2 protein complex facilitates homologous recombination-based double-strand break repair in Saccharomyces cerevisiae. Mol Cell Biol 1999, 19:768I-7687. 
11. D'Amours D, jackson SP: The yeast Xrs2 complex functions in S phase checkpoint regulation. Genes Dev 200I, 15:2238-2249.

12. Chen L, Trujillo K, Ramos W, Sung P, Tomkinson AE: Promotion of Dnl4-catalyzed DNA end-joining by the Rad50/MreII/Xrs2 and HdfI/Hdf2 complexes. Mol Cell 200I, 8: I I05-IIII.

13. de Jager M, van Noort J, van Gent DC, Dekker C, Kanaar R, Wyman C: Human Rad50/Mre II is a flexible complex that can tether DNA ends. Mol Cell 200I, 8: I I29-II 35.

14. Trujillo KM, Sung P: DNA structure-specific nuclease activities in the Saccharomyces cerevisiae Rad50*Mre I I complex. J Biol Chem 200I, 276:35458-35464.

15. Lee JH, Ghirlando R, Bhaskara V, Hoffmeyer MR, Gu J, Paull TT: Regulation of Mrell/Rad50 by NbsI: effects on nucleotidedependent DNA binding and association with Ataxia-Telangiectasie-like disorder mutantz complexes. I Biol Chem 2003, 278:45I7|-45I8I

16. de Jager M, Wyman C, van Gent DC, Kanaar R: DNA end-binding specificity of human Rad50/Mre I I is influenced by ATP. Nuc Acids Res 2002, 30:4425-443I.

17. Chen L, Trujillo KM, Van Komen S, Roh DH, Krejci L, Lewis LK, Resnick MA, Sung P, Tomkinson AE: Effect of Amino Acid Substitutions in the Rad50 ATP Binding Domain on DNA Double Strand Break Repair in Yeast. J Biol Chem 2005, 280:2620-2627.

18. Hopfner KP, Karcher A, Shin DS, Craig L, Arthur LM, Carney JP, Tainer JA: Structural biology of Rad50 ATPase: ATP-driven conformational control in DNA double-strand break repair and the ABC-ATPase superfamily. Cell 2000, 101:789-800.

19. Lowe J, Cordell SC, van den Ent F: Crystal structure of the SMC head domain: an ABC ATPase with 900 residues antiparallel coiled-coil inserted. J Mol Biol 200I, 306:25-35.

20. Hopfner KP, Craig L, Moncalian G, Zinkel RA, Usui T, Owen BA, Karcher A, Henderson B, Bodmer JL, McMurray CT, Carney JP, Petrini JH, Tainer JA: The Rad50 zinc-hook is a structure joining Mre I I complexes in DNA recombination and repair. Nature 2002, 418:562-566.

21. Strunnikov AV, Jessberger R: Structural maintenance of chromosomes (SMC) proteins: conserved molecular properties for multiple biological functions. Eur J Biochem 1999, 263:6-13.

22. Mascarenhas J, Soppa J, Strunnikov A, Grauman PL: Cell cycle dependent localization of two novel prokaryotic chromosome segregation and condensation proteins in Bacillus subtilis that interact with SMC protein. EMBO J 2002, 2I:3108-3II8.

23. Lemon KP, Grossman AD: Localization of bacterial DNA polymerase: evidence for a factory model of replication. Science 1998, 282:1516-1519.

24. Connelly JC, de Leau ES, Leach DR: DNA cleavage and degradation by the SbcCD protein complex from Escherichia coli. Nucleic Acids Res 1999, 27: 1039-1046.

25. Connelly JC, Kirkham LA, Leach DR: The SbcCD nuclease of Escherichia coli is a structural maintenance of chromosomes (SMC) family protein that cleaves hairpin DNA. Proc Natl Acad Sci U S A 1998, 95:7969-7974.

26. Liu Y, Li M, Lee EY, Maizels N: Localization and dynamic relocalization of mammalian Rad52 during the cell cycle and in response to DNA damage. Curr Biol 1999, 9:975-978.

27. Nelms BE, Maser RS, MacKay JF, Lagally MG, Petrini JH: In situ visualization of DNA double-strand break repair in human fibroblasts. Science 1998, 280:590-592.

28. Maser RS, Monsen KJ, Nelms BE, Petrini JH: hMrel I and hRad50 nuclear foci are induced during the normal cellular response to DNA double-strand breaks. Mol Cell Biol 1997, 17:6087-6096.

29. Haaf T, Golu El, Reddy G, Radding CM, Ward DC: Nuclear foci of mammalian Rad5I recombination protein in somatic cells after DNA damage and its localization in synaptonemal complexes. Proc Natl Acad Sci U S A 1995, 92:2298-2302.

30. Lisby N, Mortensen UH, Rothstein R: Colocalization of multiple DNA double-strand breaks at single Rad52 repair centre. Nat Cell Biol 2003, 5:572-577.

31. Kidane D, Sanchez H, Alonso JC, Graumann PL: Visualization of DNA double-strand break repair in live bacteria reveals dynamic recruitment of Bacillus subtilis RecF, RecO and RecN proteins to distinct sites on the nucleoids. Mol Microbiol 2004, 52:1627-1639.
32. Kidane D, Graumann PL: Dynamic formation of RecA filaments at DNA double strand break repair centres in live cells. J Cell Biol 2005, 170:357-366.

33. Kidane D, Graumann PL: Intracellular protein and DNA dynamics in competent Bacillus subtilis cells. Cell 2005, 1 22:73-84

34. Palom Y, Suresh Kumar G, Tang LQ, Paz MM, Musser SM, Rockwell $S$, Tomasz M: Relative toxicities of DNA cross-links and monoadducts: new insights from studies of decarbamoyl mitomycin C and mitomycin C. Chem Res Toxicol 2002, 15:1398-1406.

35. Jonnalagadda VS, Matsuguchi T, Engelward BP: Interstrand crosslink-induced homologous recombination carries an increased risk of deletions and insertions. DNA Repair (Amst) 2005, 4:594-605.

36. Frankenberg-Schwager M, Kirchermeier D, Greif G, Baer K, Becker M, Frankenberg D: Cisplatin-mediated DNA double-strand breaks in replicating but not in quiescent cells of the yeast Saccharomyces cerevisiae. Toxicology 2005, 2 | 2: |75-184.

37. Dusre L, Covey JM, Collins C, Sinha BK: DNA damage, cytotoxicity and free radical formation by mitomycin $C$ in human cells. Chem Biol Interact 1989, 7 I:63-78.

38. Yasbin RE, Fields PI, Andersen BJ: Properties of Bacillus subtilis 168 derivatives freed of their natural prophages. Gene 1980, I 2:155-159.

39. Sciochetti SA, Blakely GW, Piggot PJ: Growth phase variation in cell and nucleoid morphology in a Bacillus subtilis recA mutant. J Bacteriol 200I, I 83:2963-2968.

40. Chedin F, Ehrlich SD, Kowalczykowski SC: The Bacillus subtilis AddAB helicase/nuclease is regulated by its cognate $\mathrm{Chi}$ sequence in vitro. J Mol Biol 2000, 298:7-20.

41. Alonso JC, Stiege AC, Luder G: Genetic recombination in Bacillus subtilis 168: effect of $\mathrm{recN}$, recF, recH and addAB mutations on DNA repair and recombination. Mol Gen Genet 1993, 239:129-136.

42. Wang ST, Setlow B, Conlon EM, Lyon JL, Imamura D, Sato T, Setlow $P$, Losick R, Eichenberger P: The Forespore Line of Gene Expression in Bacillus subtilis. J Mol Biol 2006, 358:16-37.

43. Lin DCH, Levin PA, Grossman AD: Bipolar localization of a chromosome partition protein to Bacillus subtilis. Proc Natl Acad Sci USA 1997, 94:472I-4726.

44. Lindow JC, Kuwano M, Moriya S, Grossman AD: Subcellular localization of the Bacillus subtilis structural maintenance of chromosomes (SMC) protein. Mol Microbiol 2002, 46:997-I009.

45. Della M, Palmbos PL, Tseng HM, Tonkin LM, Daley JM, Topper LM, Pitcher RS, Tomkinson AE, Wilson TE, Doherty AJ: Mycobacterial $\mathrm{Ku}$ and ligase proteins constitute a two-component NHEJ repair machine. Science 2004, 306:683-685.

46. Michel B, Grompone G, Flores MJ, Bidnenko V: Multiple pathways process stalled replication forks. Proc Natl Acad Sci U S A 2004, 10 I: I2783- | 2788.

47. Haber JE: Partners and pathways repairing a double-strand break. Trends Genet 2000, 16:259-264.

48. Hopfner KP, Putnam CD, Tainer JA: DNA double-strand break repair from head to tail. Curr Opin Struct Biol 2002, I 2: I I5-I22.

49. Lisby M, Barlow JH, Burgess RC, Rothstein R: Choreography of the DNA damage response: spatiotemporal relationships among checkpoint and repair proteins. Cell 2004, I I 8:699-7 I3.

50. Sanchez H, Kidane D, Castillo Cozar M, Graumann PL, Alonso JC: Recruitment of Bacillus subtilis RecN to DNA DoubleStrand Breaks in the Absence of DNA End Processing. J Bacteriol 2006, I 88:353-360.

5I. Jaacks KJ, Healy J, Losick R, Grossman AD: Identification and characterization of genes controlled by the sporulation regulatory gene spoOH in Bacillus subtilis. I Bacteriol 1989, | 71:412|-4129.

52. Lewis PJ, Marston AL: GFP vectors for controlled expression and dual labelling of protein fusions in Bacillus subtilis. Gene 1999, 227:101-110.

53. Quisel JD, Burkholder WF, Grossman AD: In vivo effects of sporulation kinases on mutant Spo0A proteins in Bacillus subtilis. J Bacteriol 200I, 183:6573-6578.

54. Alonso JC, Tailor RH, Luder G: Characterization of recombination-defcient mutants of Bacillus subtilis. I Bacteriol 1988, 170:300I-3007

55. Ceglowski P, Luder G, Alonso JC: Genetic analysis of rec E activities in Bacillus subtilis. Mol Gen Genet 1990, 222:44I-445. 
56. Hopfner KP, Karcher A, Craig L, Woo TT, Carney JP, Tainer JA: Structural biochemistry and interaction architecture of the DNA double- strand break repair Mrell nuclease and Rad50-ATPase. Cell 200I, 105:473-485.

57. de Jager M, Trujillo KM, Sung P, Hopfner KP, Carney JP, Tainer JA, Connelly JC, Leach DR, Kanaar R, Wyman C: Differential arrangements of conserved building blocks among homologs of the Rad50/Mrell DNA repair protein complex. J Mol Biol 2004, 339:937-949.

58. Graumann PL, Losick R, Strunnikov AV: Subcellular localization of Bacillus subtilis SMC, a protein involved in chromosome condensation and segregation. J Bacteriol 1998, 180:5749-5755.

59. Alonso JC, Luder G, Tailor RH: Characterization of Bacillus subtilis recombinational pathways. J Bacteriol I99I, 173:3977-3980.

Publish with Bio Med Central and every scientist can read your work free of charge

"BioMed Central will be the most significant development for disseminating the results of biomedical research in our lifetime. "

Sir Paul Nurse, Cancer Research UK

Your research papers will be:

- available free of charge to the entire biomedical community

- peer reviewed and published immediately upon acceptance

- cited in PubMed and archived on PubMed Central

- yours - you keep the copyright

Submit your manuscript here:

http://www.biomedcentral.com/info/publishing_adv.asp
BiolMedcentral 